Techniques \& Culture

$4 \mid 1985$

Aspects des agricultures insolites de l'Amérique indienne

\title{
Le musée des cultures populaires à Mexico
}

\section{Marie-Noëlle Chamoux}

\section{(2) OpenEdition}

Journals

Édition électronique

URL : https://journals.openedition.org/tc/994

DOI : $10.4000 /$ tc. 994

ISSN : 1952-420X

Éditeur

Éditions de l'EHESS

Édition imprimée

Date de publication : 1 février 1985

ISSN : 0248-6016

Référence électronique

Marie-Noëlle Chamoux, «Le musée des cultures populaires à Mexico », Techniques \& Culture [En ligne],

4 | 1985, mis en ligne le 26 janvier 2006, consulté le 29 septembre 2022. URL : http://

journals.openedition.org/tc/994; DOI : https://doi.org/10.4000/tc.994

Ce document a été généré automatiquement le 29 septembre 2022.

Tous droits réservés 
Le musée des cultures populaires à Mexico

Marie-Noëlle Chamoux 